Estado del conocimiento y conservación de

lagomorfos en peligro y críticamente en

peligro a nivel mundial

\title{
State of knowledge and conservation of endangered and critically endangered lagomorphs worldwide
}

\section{Consuelo Lorenzo ${ }^{1^{*}}$, Tamara M. Rioja-Paradela² and Arturo Carrillo-Reyes ${ }^{3}$}

'El Colegio de La Frontera Sur, Unidad San Cristóbal. Carretera Panamericana y Periférico Sur s/n, Barrio de María Auxiliadora. San Cristóbal de Las Casas, Chiapas, 29290, México. E-mail: clorenzo@ecosur.mx (CL)

${ }^{2}$ Universidad de Ciencias y Artes de Chiapas. Libramiento Norte Poniente 1150, Colonia Lajas Maciel. Tuxtla Gutiérrez, Chiapas, 29000, México. E-mail: tamara.rioja@unicach.mx (TMRP)

${ }^{3}$ Oikos: Conservación y Desarrollo Sustentable, A. C. Bugambilias 5, San Cristóbal de Las Casas, Chiapas, 29267, México. E-mail: acarrillo@oikos.org.mx (ACR)

${ }^{*}$ Corresponding author

Introduction: Lagomorphs (rabbits, hares, and pikas) are widely distributed in every continent of the world, except Antarctica. They include 91 species: 31 rabbits of the genera Brachylagus, Bunolagus, Caprolagus, Nesolagus, Pentalagus, Poelagus, Prolagus, Pronolagus, Romerolagus, and Sylvilagus; 32 hares of the genus Lepus and 28 pikas of the genus Ochotona. According to the International Union for Conservation of Nature (IUCN 2014), the list of threatened species of lagomorphs includes one extinct, three critically endangered, ten endangered, five near threatened, five vulnerable, 61 of least concern, and six with deficient data. Although a rich diversity of lagomorphs and endemic species exists, some of the wild populations have been declining at an accelerated rate, product of human activities and climate change. In order to evaluate specific conservation actions for species at risk in the near future, the aim of this study is to determine the state of knowledge of endangered and critically endangered species and conservation proposals based on recent studies. This work should serve as a starting point for proposing management and habitat conservation plans for these species and filling the information gaps to address them as soon as possible.

Methods: We performed an analysis of the recent trends in the state of knowledge of worldwide endangered and critically endangered lagomorphs, based on the compilation of the recent bibliographic citations in the IUCN list of endangered species (2014), the Lagomorphs Specialist Group of the IUCN web page, and on published studies focusing on these species. Each study was divided into various topics to know those that need to be addressed. We show detailed information for species that are at risk of extinction in the near future (critically endangered and endangered categories), describing the threats to their populations and existing conservation proposals.

Results: A total of 13 endangered and critically endangered species of lagomorphs have been the subject of study with a total of 78 contributions, of which the most frequently represented (25) refer to phylogeny, systematics, taxonomy, and evolution, followed by conservation (18), and ecology (14); the least represented are studies of reproduction and morphology with only one each. The critically endangered and endangered species have restricted distributions and in general, their threat factors are introduction of exotic species; habitat loss due to development of human settlements and productive activities; induced fires for the growth of new grass shoots for livestock; poaching; and the presence of predators and feral dogs.

Discussion and Conclusions: Worldwide human activities have affected the survival of species of lagomorphs, especially those with restricted distributions. Less than $55 \%$ (7 species) of the total number of species of endangered and critically endangered lagomorphs has been subject of specific study in recent works (2011 to date); moreover, in some cases only one publication was found. Although recent efforts have generated knowledge about the state of conservation and threat factors of some species of endemic lagomorphs, more detailed and long-term studies are needed to propose management and conservation of their habitats in collaboration with society and different academic and institutional sectors.

Key words: Conservation, endemism, hares, lagomorphs, pikas, rabbits, risk category. 


\section{Introduction}

Lagomorphs (Order Lagomorpha) are comprised by the families Ochotonidae (pikas) and Leporidae (rabbits and hares). Approximately 91 species, including 31 rabbits of the genera Brachylagus, Bunolagus, Caprolagus, Nesolagus, Oryctolagus, Pentalagus, Poelagus, Prolagus, Pronolagus, Romerolagus, and Sylvilagus; 32 hares of the genus Lepus and 28 pikas of the genus Ochotona (Chapman and Flux 2008; Table 1) have been described. They are widely distributed with native and introduced species in all continents of the world except Antarctica, and occur from sea level to 5,000 $\mathrm{m}$ from $83^{\circ} \mathrm{N}$ (L. arcticus) to $45^{\circ} \mathrm{S}$ (L. europaeus; Chapman and Ceballos 1990; Flux and Angermann 1990).

Lagomorphs are associated with fertility since some species are very prolific; they give birth to numerous litters, reproduce almost all year round, and have short gestation periods. Ecologically, they are an essential part of the food chain. Their size and abundance supports a community of predators from small to medium size. Lagomorph populations maintain weasels, foxes, coyotes, cats, snakes, and many birds of prey (Chapman and Flux 1990).

The order is ancient, with fossil records dating back to more than 50 million years ago. They are adapted to a wide variety of environments, including scrub, grassland, temperate, cloud and rain forests, deserts, and agricultural areas. Despite the importance of hares and rabbits in many places, they are considered pests in some regions because they affect agriculture. Therefore, they are subject to control programs, with the hares Lepus alleni, $L$. californicus, L. americanus, L. europaeus, L. nigricollis, L. townsendii, and L. yarkandensis, and the common rabbit or European rabbit Oryctolagus cuniculus, included in the list of the 100-most damaging invasive alien species of the world by the International Union for the Conservation of Nature (IUCN). Their distribution is quite wide and in some countries, such as Australia, they have become a plague due to the lack of natural predators or competitors (Flux et al. 1990).

In spite of the high species diversity and numerous endemic species, some of the wild populations of lagomorphs have been declining at an accelerated rate. The causes have been attributed to different risk factors, such as habitat alteration, deforestation or clearing of natural habitats for agriculture, which have increased the degree of isolation of populations, and global climate change. These factors have affect several species of pikas, such as O. hyperborea, O. nubrica, O. thibetana, and O. pusilla (Smith et al. 1990). Threats to hares and rabbits include hunting for food and trade of their meat and skin, which have affected populations of L. timidus, L. capensis, and S. cunicularius. However, other species remain abundant and are considered as game animals, such as S. aquaticus, S. audubonii, S. floridanus, and S. nuttallii (Chapman and Ceballos 1990).

Productive human activities such as plant cover transformation and intensive land use changes (e.g. increasing human settlements, induced fires, and deforestation for agricultural and development activities) have also had negative effects on populations of lagomorphs. In insular populations of hares and rabbits the introduction of exotic species (rodents and domestic cats) that compete for space and resources, and wild predators (birds, reptiles and carnivorous mammals) that prey on them, could have caused them a serious risk of extinction in the medium term (Lorenzo et al. 2014).

Although a great number of species of lagomorphs exists, knowledge of different aspects of their basic biology and natural history (behavior, use of habitat, home range size, population size, reproduction, feeding) is scarce for many threatened and endangered species with 
very restricted ranges (insular species: e. g. L. insularis, S. mansuetus, S. graysoni). Moreover, dynamic populations studies should be performed considering other widespread species, subjected to different natural pressures (competition, predation); population displacements due to sharing their range with other aggressive lagomorph species (S. transitionalis-S. floridanus; L. alleni-L. californicus, californicus), and by human activities that have caused habitat transformation, as in Brachylagus idahoensis, Bunolagus monticularis, and Poelagus majorita (Chapman and Ceballos 1990; Dobler and Dixon 1990; Duthie and Robinson 1990; Flux and Angermann 1990).

The objective of our study is to determine the state of knowledge and conservation status of lagomorph species worldwide at risk of extinction in the near future based on recent studies considering the tendencies of the topic areas dealt with at present and detailing data and existing conservation proposals up to date. This study should serve as a starting point to propose plans for habitat management and conservation of these species and identify the information gaps to address them as soon as possible.

\section{Material and methods}

State of knowledge. To evaluate current trends in the state of knowledge of lagomorphs under endangered and critically endangered status, we considered the citations of the IUCN Lagomorphs Specialist Group (2014), and compiled citations of recent published studies focusing on these lagomorphs.

Conservation. We detailed information about the conservation proposals for lagomorphs, taking into consideration the conservation actions according to the IUCN list of endangered species (2014), and compiled citations of published studies on the current situation of these species.

\section{Results}

Of all the species of lagomorphs worldwide, one (Prolagus sardus) is extinct, three are critically endangered, 10 endangered, five near threatened, five vulnerable, 61 species of least concern, and six with deficient data. It is a concern that in a recent analysis, Leach et al. (2014) predict a significant reduction in the distribution area of the majority of the species when considering the effect of climate change on them. We detail the existing information of the species critically endangered and endangered according to the IUCN (2014). Their approximate distributions are shown in Figure 1.

A total of 13 endangered and critically endangered species of lagomorphs have been the subject of recent studies with a total of 78 contributions, of which the most frequently represented (25) refer to phylogeny, systematics, taxonomy and evolution, followed by conservation (18), and ecology (14); the least represented are studies of reproduction and morphology with only one each (Table 1). Topic areas required to attend conservation issues and existing conservation proposals by species are show in Table 2 .

\section{Critically endangered species}

Bunolagus monticularis. This species distributed in South Africa is endemic to central Karoo and located in an area $<500 \mathrm{~km}^{2}$. The riverine rabbit inhabits riparian vegetation on alluvial soils adjacent to seasonal rivers, but its habitat has been highly fragmented and transformed (60\%). 
Its population has declined drastically; the few subpopulations have less than 50 individuals, and they are isolated due to anthropogenic barriers; therefore, today this lagomorph is critically endangered (South African Mammal CAMP Workshop 2013, IUCN 2014). According to Leach et al. (2014), the bioclimatic envelope of the riverine rabbit is predicted to have declined $85 \%$ by 2080.

Conservation proposals. Currently, the riverine rabbit work groups have been performing surveys, monitoring, outreach, and education (Collins et al. 2004). They suggest that the preservation of suitable habitat of the riparian rabbit must receive the highest priority for restoration and breeding programs; translocations and reintroductions are inappropriate at this time. On the other hand, Hughes et al. (2008) developed a habitat model to assist in identifying isolated populations, which would contribute to different conservation efforts related to introduction or reintroduction of the species, taking into account the possible effects of global change; according to their results, they considered current breeding programs in captivity should be reevaluated. No data have been published about its habitat, ecology, genetics or population status since 2008 , so we recommend evaluating this species to update information.

Ochotona argentata. The silver pika is critically endangered (Smith and Johnston 2008), and occupies a very restricted area $(2 \times 1.5 \mathrm{~km})$ in the isolated Helan Shan Mountains in central China (Erbajeva and Ma 2006). Formerly included as subspecies of O. alpina and of O. pallasi, the silver pika is unique in morphology, number of chromosomes, molecular characteristics and vocalizations (Smith and Xie 2008). However, there is confusion whether O. argentata and

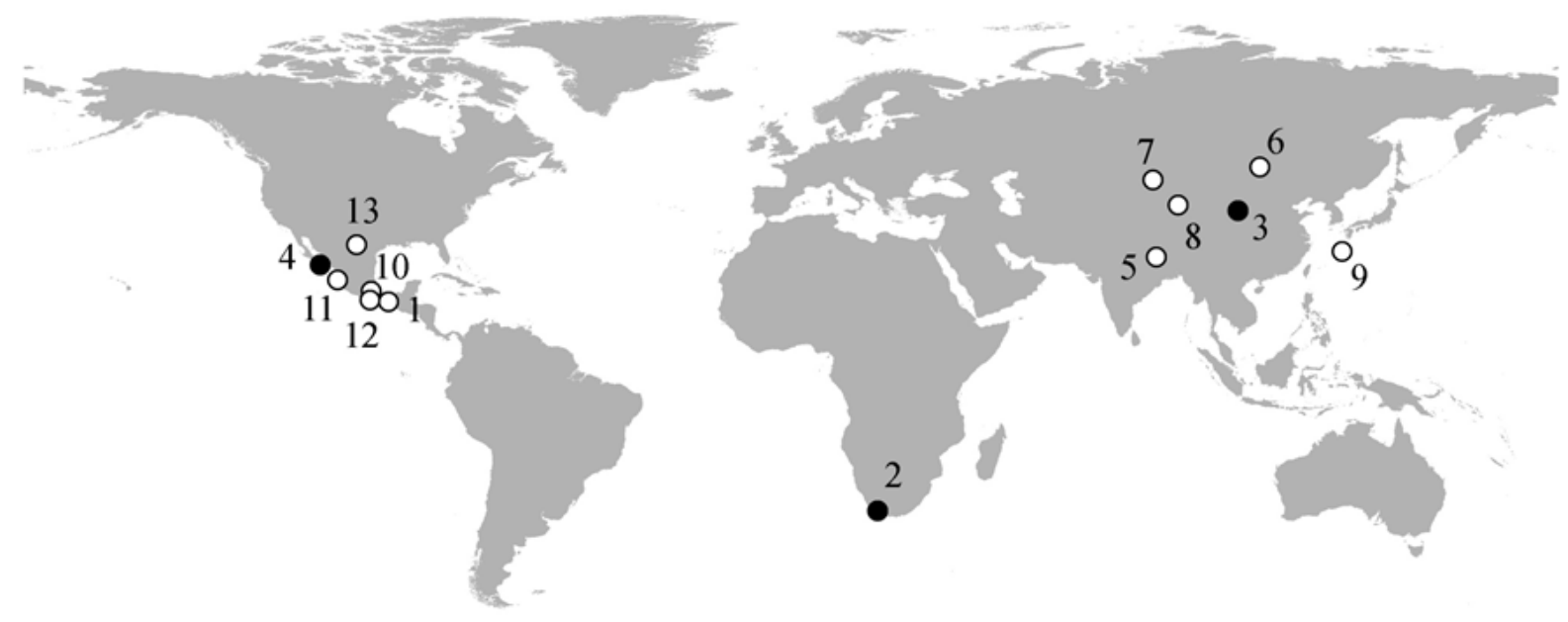

Figure 1. Approximate distributional locations of the endangered (open circles) and critically endangered (closed circles) lagomorph species. (1) Lepus flavigularis; (2) Bunolagus monticularis; (3) Ochotona argentata; (4) Sylvilagus mansuetus; (5) Caprolagus hispidus; (6) Ochotona hoffmanni; (7) Ochotona iliensis; (8) Ochotona koslowi; (9) Pentalagus furnessi; (10) Romerolagus diazi; (11) Sylvilagus graysoni; (12) Sylvilagus insonus; (13) Sylvilagus robustus.

O. helanshanensis are separate species (Hoffmann and Smith 2005). A detailed comparative study of Ochotona argentata, O. pallasi and O. alpina showed conclusively that silver pikas differ significantly from the latter species by several characters and features, thus confirming O. argentata as an independent species inhabiting Central Asia (Erbajeva and Ma 2006). Additionally, O. argentata is a well-defined taxon within the "pallasi" group (Lissovsky et al. 2007).

Conservation proposals. Information regarding its life history remains unknown (Chung 2008) and apparently, its range of occurrence and area of occupancy have declined dramatically in 
Table 1. Topics of published studies of endangered and critically endangered lagomorphs worldwide. Citations obtained from the website of the Lagomorph Specialist Group of the International Union for Conservation of Nature (IUCN 2014).

\begin{tabular}{|c|c|c|c|c|c|c|c|c|c|c|}
\hline 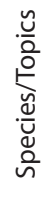 & 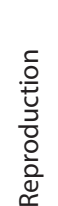 & 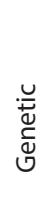 & $\begin{array}{l}\text { के } \\
\text { 응 } \\
\text { प्र }\end{array}$ & $\begin{array}{l}\text { बे } \\
\frac{0}{0} \\
\frac{0}{n} \\
\frac{1}{2}\end{array}$ & 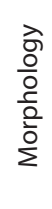 & 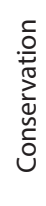 & 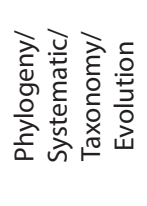 & 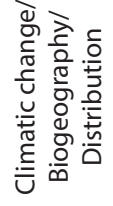 & 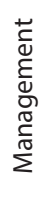 & $\begin{array}{l}\bar{\pi} \\
\stackrel{0}{\circ}\end{array}$ \\
\hline
\end{tabular}

\begin{tabular}{|c|c|c|c|c|c|c|c|c|c|c|}
\hline Bunolagus monticularis & & & & & & 20,87 & & 37,44 & & 4 \\
\hline Caprolagus hispidus & & & $4,5,93$ & & & 57 & 79 & 44 & & 6 \\
\hline Lepus flavigularis & 71 & & $\begin{array}{c}9,72 \\
81\end{array}$ & & 77 & $\begin{array}{c}13,54 \\
73\end{array}$ & & & & 8 \\
\hline Ochotona argentata & & & & & & 18,85 & $\begin{array}{l}24,31,33 \\
34,36,51\end{array}$ & 86 & & 9 \\
\hline Ochotona hoffmanni & & & & & & 18 & $\begin{array}{c}30,31,32 \\
33,34,36 \\
51\end{array}$ & 44 & & 9 \\
\hline Ochotona iliensis & & & 45 & & & $\begin{array}{c}18,47 \\
48\end{array}$ & $\begin{array}{c}34,42,43 \\
67,68,88 \\
102\end{array}$ & & & 11 \\
\hline Ochotona koslowi & & & $\begin{array}{l}31 \\
101\end{array}$ & & & $\begin{array}{c}46,49 \\
103\end{array}$ & $\begin{array}{c}42,50,68 \\
102\end{array}$ & 44 & & 10 \\
\hline Pentalagus furnessi & & 1,66 & 41 & & & 92 & & 44 & 95 & 6 \\
\hline Romerolagus diazi & & 66 & $\begin{array}{l}59,74 \\
80,96\end{array}$ & 2,75 & & & & & 60 & 8 \\
\hline Sylvilagus graysoni & & & & & & & & 44 & & 1 \\
\hline Sylvilagus insonus & & & & & & & & 44 & & 1 \\
\hline Sylvilagus mansuetus & & & & & & 7,52 & & 44 & & 3 \\
\hline Sylvilagus robustus & & $\begin{array}{r}63 \\
64 \\
\end{array}$ & & & & & & & & 2 \\
\hline Total & 1 & 5 & 14 & 2 & 1 & 18 & 25 & 10 & 2 & 78 \\
\hline
\end{tabular}

recent years. The abundance and biology of the silver pika are poorly understood (Chung 2008). Ochotona argentata is under the threat of range contraction due to continuing global warming (Ge et al. 2012). Conservation proposals are to perform necessary observations and follow recommendations about their conservation status (Formozov 1997; Formozov et al. 2004).

Sylvilagus mansuetus. The San Jose brush rabbit is endemic to the San Jose Island $\left(194 \mathrm{~km}^{2}\right)$ in the Gulf of California, Baja California Sur. This island is a protected natural area since 1978 (Semarnat 2010), where it is possible to find exotic mammals (cats, goats, and donkeys; Wood et al. 2002, Álvarez-Castañeda and Ortega-Rubio 2003). The rabbit's habitat (xeric) has been altered only slightly, without human settlements and infrastructure; xeric vegetation cover is the adequate for the species activities since they were detected in two breeding sites under the base of a cardon cactus (Pachycereus pringley) near a desert thorn (Lycium sp.) patch in November 2008 (Lorenzo et al. 2011). However, the possible development of a resort with a golf course, private airport, and a small marina, as well as the re-opening of a salt mine that was intensively exploited and which would result in workers accompanied by dogs and cats, would contribute substantially to predation of rabbits on the island (Lorenzo et al. 2014). 
Table 2. Research areas required to address conservation issues and actions proposed for species of critically endangered (CE), and endangered $(E)$ lagomorphs worldwide.

\begin{tabular}{|c|c|c|}
\hline Species & $\begin{array}{l}\text { Research areas required to address } \\
\text { conservation issues }\end{array}$ & Conservation actions proposed \\
\hline $\begin{array}{l}\text { Bunolagus } \\
\text { monticularis (CE) }\end{array}$ & $\begin{array}{l}\text { Natural history, ecology, evolution, } \\
\text { management }\end{array}$ & $\begin{array}{l}\text { Performing surveys; monitoring populations; outreach, and education; } \\
\text { preservation of suitable habitat; restoration; breeding programs, } \\
\text { translocations; and reintroductions. }\end{array}$ \\
\hline Caprolagus hispidus (E) & $\begin{array}{l}\text { Natural history, conservation, } \\
\text { evolution, biogeography, } \\
\text { distribution, management }\end{array}$ & $\begin{array}{l}\text { Local education; adequate grassland management; monitoring } \\
\text { populations; captive breeding program; management plan. }\end{array}$ \\
\hline Lepus flavigularis (E) & $\begin{array}{l}\text { Natural history, evolution, } \\
\text { biogeography, distribution, } \\
\text { management }\end{array}$ & $\begin{array}{l}\text { Monitor populations; use and manage rangelands in the paddocks; } \\
\text { handle induced grassland fires properly; avoid hare hunting pressure; } \\
\text { environmental education programs; translocation program. }\end{array}$ \\
\hline Ochotona argentata (CE) & $\begin{array}{l}\text { Natural history, ecology, } \\
\text { biogeography, distribution, } \\
\text { management }\end{array}$ & Perform necessary observations to know their conservation status. \\
\hline Ochotona hoffmanni (E) & $\begin{array}{l}\text { Natural history, ecology, } \\
\text { conservation, biogeography, } \\
\text { distribution, management }\end{array}$ & $\begin{array}{l}\text { Establish objectives for its conservation, and a monitoring program } \\
\text { with more studies. }\end{array}$ \\
\hline Ochotona iliensis (E) & $\begin{array}{l}\text { Natural history, ecology, } \\
\text { biogeography, distribution, } \\
\text { management }\end{array}$ & $\begin{array}{l}\text { Establish conservation action objectives and a monitoring program } \\
\text { with more studies. }\end{array}$ \\
\hline Ochotona koslowi (E) & $\begin{array}{l}\text { Natural history, biogeography, } \\
\text { distribution, management }\end{array}$ & More fieldwork to develop and implement conservation action plans. \\
\hline Pentalagus furnessi (E) & All & $\begin{array}{l}\text { Restriction of extensive grazing in mature forests; control of predators } \\
\text { and cessation of road construction that may be favoring predator } \\
\text { expansion. }\end{array}$ \\
\hline Romerolagus diazi (E) & $\begin{array}{l}\text { Natural history, conservation, } \\
\text { evolution, biogeography, } \\
\text { distribution, management }\end{array}$ & $\begin{array}{l}\text { Protect their habitat through appropriate management and rational } \\
\text { exploitation of the forests; hunting control and its regulation; education } \\
\text { campaigns; population management in captive colonies. }\end{array}$ \\
\hline Sylvilagus graysoni (E) & All & $\begin{array}{l}\text { A detailed long-term study to identify the current state of conservation } \\
\text { and the basic biological characteristics. }\end{array}$ \\
\hline Sylvilagus insonus (E) & All & $\begin{array}{l}\text { Intensive studies to determine whether this species still survives and } \\
\text { confirm its current local distribution, habitat requirements and a risk } \\
\text { assessment study on their survival. }\end{array}$ \\
\hline Sylvilagus mansuetus (CE) & All & $\begin{array}{l}\text { Assess pressures caused by the destruction of the habitat and illegal } \\
\text { hunting; management programs to eradicate exotic fauna and control } \\
\text { hunting. }\end{array}$ \\
\hline Sylvilagus robustus (E) & All & $\begin{array}{l}\text { Monitoring populations; detailed studies to determine the best actions } \\
\text { for its conservation; establishment of protected areas and appropriate } \\
\text { management plans. }\end{array}$ \\
\hline
\end{tabular}

In addition, various animals are predators of S. mansuetus, including feral cats (Felis sylvestris; Bonnaud et al. 2011) and ringtails (Bassariscus astutus) although the latter are opportunistic (Lorenzo et al. 2011). Reptiles include vipers as rattlesnakes (Crotalus enyo, C. mitchelli, C. ruber lucanensis) and bull snakes (Pituophis melanoleucus bimaris and P. vertebralis; Espinosa-Gayosso and Álvarez-Castañeda 2006; Lorenzo et al. 2014). Avian predators include Osprey (Pandion haliaetus), Red-tailed hawk (Buteo jamaicensis), Peregrine falcon (Falco peregrinus), and American kestrel (F. sparverius; Cody and Velarde 2002).

The greatest impact on the rabbit population on this island is the presence of wild cats in high density, which may be preying on both young and adult rabbits. In addition, some fishermen have admitted to hunting rabbits occasionally (Lorenzo et al. 2011), which may be factors that result in the low population densities on this island. If the pressure from feral cats is not reduced and hunting pressure continues, the rabbit population could be at risk of extinction in the 
medium term (Lorenzo et al. 2014). According to Leach et al. (2014) the bioclimatic envelope of the San Jose brush rabbit is predicted to have decreased $25 \%$ by 2080 .

Conservation proposals. Although S. mansuetus is entirely distributed within a protected area, it is urgent to assess pressures caused by the destruction of the habitat and illegal hunting (sport or subsistence) which have been previously reported (Gómez-Nisino 2006; Lorenzo et al. 2011) and considered within its management programs to eradicate exotic fauna and control hunting. It is necessary to develop research projects to determine population dynamics, reproduction, ethology, and other aspects of its biology and ecology that have been ignored.

\section{Endangered species}

Caprolagus hispidus. This species is distributed in South Asia; it is located in Bangladesh, India, Nepal and Bhutan, possibly covering an area from 11 to $500 \mathrm{~km}^{2}$ of tall grasslands with very fragmented populations. It is currently listed as endangered because its habitat has been reduced dramatically by anthropogenic activity, such as agriculture, urban development, and the burning of grasslands. Studies show that the species ecology is subject to the spatial and temporal dynamics of these grasslands (Maheswaran and Smith 2008; Aryal et al. 2012; Tandan et al. 2013; IUCN 2014). According to Leach et al. (2014), the bioclimatic envelope of the hispid hare is predicted to have increased $21 \%$ by 2080 .

Conservation proposals. The hispid hare appears not only in Appendix I of CITES but in Schedule I of the Act on Protection of Wildlife in India and in Schedule I of the National Parks and Conservation Measures Wildlife Nepal. In addition, C. hispidus occurs in several protected areas along India. However, further studies on its biology and ecology, such as presence/absence, distribution, movement patterns, behavior, reproduction, and studies of the possible long-term effects of activities such as the burning of grasslands, harvesting, and livestock grazing are needed. A return to the natural system would help prevent the extirpation of $C$. hispidus, as well as other native species. Local education regarding the status of $C$. hispidus is necessary, including educating staff of reserves where C. hispidus occurs (Maheswaran and Smith 2008; Aryal and Kumar 2010; IUCN 2014).

Aryal et al. (2012) recommend a change to the timing of grass burning to either before or after the hispid hare breeding season to reduce the direct (burning, destruction of nests) and indirect (increased risk of predation) negative effects of such grassland management on hare populations. Population management strategies and a field-based conservation captive breeding program should be implemented immediately to maintain a viable population of the hispid hare in certain protected areas. Finally, Tandan et al. (2013) recommend that management authorities should prepare a species-focused management plan to conserve and monitor the hispid hare population and other small mammals of the region.

Lepus flavigularis. The Tehuantepec hare is located only in four disjunct populations in the surroundings of Laguna Inferior and Laguna Superior in the Tehuantepec Isthmus, Oaxaca in an approximate area of $673 \mathrm{~km}^{2}$ (Cervantes et al. 2008; Lorenzo et al. 2014). This lagomorph inhabits open grasslands with nanche (Byrsonima crassifolia), morro (Crescentia alata), and xeric shrub with the presence of tree species and it is threatened by physical conditions (Carrillo-Reyes et al. 2012; Lorenzo et al. 2014). Change in land use, ranging from the increase of human settlements to bad management and lack of control of production activities, such as ranching and burning of pastures for seasonal agriculture, has resulted in habitat fragmentation of the Tehuantepec hare. Therefore, existing populations are almost completely isolated and most have little genetic viability within them, aggravating their situation (Rioja et al. 2011; Lorenzo et al. 2014). Excessive hunting is another anthropogenic factor that has caused the decrease of population densities of 
this species, contributing to its current situation (Lorenzo et al. 2014). A recent modelling analysis concluded that the Tehuantepec jackrabbit population of Santa Maria del Mar, Oaxaca is at high risk of extinction (Rioja et al. 2012). In this analysis, the population survived over the 500 years of simulation only in the model that involved hunting, besides the base model. The effects of three catastrophic scenarios in combination, as well as inbreeding, increased the risk of extinction up to $100 \%$ in an average of $41.60 \pm 25.88$ years.

Conservation proposals. Monitoring the Tehuantepec jackrabbit's populations continuously in the study area is recommended, as well as undertaking collaborative activities among academic, governmental, and social sectors proposing actions to use and manage rangelands in the paddocks; handle induced grassland fires properly; avoid hare hunting pressure; implement mitigation actions for the establishment of wind farms in one of the populations; and carry out environmental education programs for residents of the study area starting from the basic level (Lorenzo et al. 2014; Rioja and Carrillo-Reyes 2014). Rioja et al. (2012) also proposed assessing the relevance of a translocation program to the Santa Maria del Mar population, with individuals from other populations.

Ochotona hoffmanni. Hoffmann's pika occupies a limited area in Mongolia (Bayan-Ulaan Mountains) and Russia (province of Chita, Crest of Erman; area of 600 km²; Formozov 1997; Formozov and Baklushinskaya 1999). This species was previously included as subspecies of O. alpina and subsequently elevated to a specific rank (Formozov et al. 1996; Formozov and Baklushinskaya 1999; Formozov et al. 2004; Hoffmann and Smith 2005). According to Leach et al. (2014), the silver pika's bioclimatic envelope is predicted to have declined $90 \%$ by 2080.

Conservation proposals. No further information is available on other aspects of this species (Chung 2008). More studies are needed to establish objectives for its conservation and a monitoring program.

Ochotona iliensis. Only 27 records of the Ili pika are known, in addition to ten sightings confirmed by local shepherds. This species is distributed exclusively in the mountain ranges of north Tian Shan (Mt. Poluokenu, Mt. Yilianhabierduo, Mt. Tiangeer) and south Tian Shan (Mt. Tieersiketaniao, Mt. Keketiegaitaniao) of China. Populations of Ili pika are fragmentally distributed and its population estimation could be of 2,000 mature individuals existed in the early 1990's (Li 2004; Li and Smith 2005). Recent studies on this pika have reported that no existing populations have been found in more than half ( $57 \%$ ) of the sites where the species was originally recorded 10-20 years ago, which indicate that may be undergoing a rapid extinction (Li and Smith 2005). The possible population decline might have been due to: 1) plague, 2) expansion of human population and pastoral activities in higher elevations; and 3) global climate change forcing Ili pika to retreat to higher elevations for suitable habitat. This combination of factors has contributed to their reduction (Li and Smith 2005).

Conservation proposals. Low population density and fragmented distribution of Ili pika could led to low gene flow. An ex situ study conducted by Li et al. (1994) was able to demonstrate that Ili pika was suitable to be kept in an artificial environment with high adaptability to lower elevation and types of vegetation, which opened up possibilities for an artificial breeding program for rescue (Chung 2008). More studies are needed to establish objectives of conservation action and a monitoring program for this species.

Ochotona koslowi. Koslov's pika occupies the high isolated mountains near the junction of the Qinghai province, Xinjiang Uygur and Xizang autonomous regions in central China. According to Li et al. (2000) Kozlov's Pika was distributed in central, west Mt. Kunlun, south Mt. Kongka and Aerjin Mountain Nature Reserve (Aqikekule Lake, Tuzi Lake and Yueya River). Kozlovi's pika was rediscovered in 1984 after it was described nearly a century ago (Zheng 1986). A recent expedition 
led by Li et al. (2000) in Aerjin Mountain Nature Reserve concluded that it had a very restricted and fragmented distribution ( $800 \mathrm{~km}$ between subpopulation). Evidence has shown that the range of this species could be extended further to the west of what was previously thought (Smith 2008). In addition, its population dynamics remains uncertain. The limited distribution area and ancestral skull properties suggest that Kozlov's pika may be an ancestral species in decline (Li et al. 2006). According to the bioclimatic envelope modeled by Leach et al. (2014), Kozlov's pika is predicted to decrease to total extinction.

Conservation proposals. More fieldwork is necessary to develop and implement conservation action plans for this species. It is likely a sister species of O. ladacensis (Yu et al. 2000). Current distribution and status in two of the three distributed locations (e.g. central, west Mt. Kunlun and S Mt. Kongka) are unknown. Since 1998, there has been little new information on Kozlov's pika. Collection of this preliminary information was made possible only during a field survey of chiru (Pantholops hodgsonii). Strengthened cooperation is needed to protect this rare and unique animal (Li et al. 2006).

Pentalagus furnessi. The Amami rabbit occupies only two small islands in the Ryukyu Islands South of Japan within an area of $335 \mathrm{~km}^{2}$. The habitat of the only black rabbit consists of evergreen forest and areas where perennial grasses dominate. In 2003 the size of its population was estimated from 2,000 to 4,800 individuals in four habitat fragments in Amami Island in addition to a small town in Tokuno Island. The species is threatened by invasive mongooses, feral cats and dogs, as well as by deforestation and development projects (Sugimura et al. 2000; Sugimura et al. 2003; Sugimura and Yamada 2004; Yamada 2008; Sugimura et al. 2014). Recently Abrantes et al. (2011) reported that $P$. furnessi has a particular genetic alteration which in exposure to the Myxoma virus (MV) it can potentially cause an epizootic disease with particularly high mortality rates. Kubo et al. (2014) reported dermatitis associated with a parasite. In contrast to other species, the Amami rabbit's bioclimatic envelope is predicted to increase $150 \%$ by 2080 (Leach et al. 2014).

Conservation proposals. Restriction of extensive grazing in mature forests, control of predators, and cessation of road construction that may be favoring predator expansion in the forests, are all indicated (Sugimura et al. 2000).

Romerolagus diazi. The volcano rabbit is located in the Transverse Neovolcanic Belt and restricted to three discontinuous areas with a total of $280 \mathrm{~km}^{2}$ covering the slopes of the Popocatepetl, Iztaccihuatl (Sierra Nevada), El Pelado, and Tlaloc (Sierra Chichinautzin) volcanoes in central Mexico. The species is located from 2,800 to 4,250 m in pine forests (Pinus) with grasses (zacatón, mainly Muhlenbergia macroura, Festuca rosei, F. amplissima and Stipa ichu) and rocky substrate (Fa and Bell 1990; Sánchez-Trocino et al. 2013). Its predators are weasels (Mustela frenata), bobcats (Lynx rufus), coyotes (Canis latrans), rattlesnakes (Crotalus spp.), and the Red-tailed hawk (Buteo jamaicensis; Fa and Bell 1990).

Its habitat has been threatened by forest destruction by burning, invasive agriculture, overgrazing by cattle and sheep, over-exploitation of wood and cutting of zacatón for brush, manufacturing, housing development, and poaching. A substantial area of its original habitat has disappeared due to the expansion of Mexico City and a rapid increase of rural settlements around its habitat (Fa and Bell 1990; Romero and Velazquez 1994; Velázquez et al. 1996; Portales et al. 2004). Studies, as that of Martínez-García (2011), show that in certain areas as Altzomoni, in sites as El Arco and El Pinar population density of this rabbit is very close to its carrying capacity. Moreover, Rizo-Aguilar et al. (2014) found faecal cortisol metabolites levels significantly higher in animals from the disturbed sites indicating potentially higher physiological stress intensities.

Conservation proposals. It is necessary to protect $R$. diazi's habitat through appropriate management and rational exploitation of the forests where it lives, both by governmental and 
social sectors. Hunting control and its regulation must be compatible with the recovery of other areas and wildlife conservation. Education campaigns at different levels and spreading the impact of land use on wildlife conservation are necessary, as many locals are unaware of the protected status of $R$. diazi. The species requires a proper population management in captive colonies in zoological parks as in Mexico City (Fa and Bell 1990).

Sylvilagus graysoni. The Tres Marias rabbit is endemic of the Tres Marias Islands, Nayarit, Mexico with two recognized subspecies. S. g. graysoni in the Maria Madre (the largest with $145 \mathrm{~km}^{2}$ ), Maria Magdalena, and Maria Cleofas islands and S. g. badistes in San Juanito Island. The species is located in dry deciduous and moist forests, characterized by dense cover with many tree species (Chapman and Ceballos 1990).

The islands have been a high security prison of the Mexican Government, so the presence of a large number of people has resulted in extensive ecological disturbances. Although Maria Magdalena Island has been designated an ecological reserve by the Mexican Government, a large extension of natural vegetation areas has been destroyed in Maria Madre and Maria Cleofas islands by local inhabitants. According to Leach et al. (2014), the Tres Marias cottontail's bioclimatic envelope is predicted to have declined $20 \%$ by 2080.

In addition, the rats Rattus rattus were accidentally introduced in all the islands, and the Whitetailed deer (Odocoileus virginianus) and domestic goats were purposely introduced to the Maria Magdalena Island. These introduced species have caused profound changes in the ecological conditions of the islands and have caused great impact on native wildlife (Chapman and Ceballos 1990). The greatest threats to the species are introduced species that compete for food, alter native vegetation, and prey on rabbits, causing habitat destruction in addition to that one caused by the human inhabitants (Chapman and Ceballos 1990).

Conservation proposals. A detailed long-term study strongly recommended to identify the current state of conservation and the basic biological characteristics of the species (Chapman and Ceballos 1990).

Sylvilagus insonus. The Omiltemi rabbit is restricted to a highly fragmented area less than 500 $\mathrm{km}^{2}$ in a natural reserve area, Omiltemi State Park in the Sierra Madre del Sur, Guerrero, Mexico at an elevational range from 2,133 to 3,048 m (Chapman and Ceballos 1990; Cervantes and Lorenzo 1997). This species is the rarest and least understood of all lagomorphs, definitely known from only three specimens with questionable diagnosis (Nelson 1904; Wilson 1991; Cervantes and Lorenzo 1997). Prior to recovering of a skin of a hunted specimen donated by local residents in 1998 (Cervantes et al. 2004), many sources had considered this species among rabbits the most threatened in the world (Chapman et al. 1990) and possibly extinct (Caughley and Gunn 1996; MacPhee and Fleming 1997, 1999; Cervantes et al. 2004). The consequences of deforestation and excessive hunting may be important factors that have threatened this species and prevented its observation in field (Jiménez-Almaráz et al. 1993). According to Leach et al. (2014), the Omiltemi rabbit's bioclimatic envelope is predicted to have decreased $80 \%$ by 2080 .

Conservation proposals. It is of utmost importance to take measures to ensure the survival of all Omiltemi State Park fauna and their habitats. Intensive studies are necessary to determine whether S. insonus still survives and confirm its current local distribution. Studies should focus on habitat requirements and a risk assessment study on the survival of this threatened species. Until such information is available, a comprehensive conservation strategy of this species and its habitat cannot be developed.

Sylvilagus robustus. The Robust cottontail rabbit is found in isolated mountains in western Texas, eastern New Mexico (U. S. A.) and northern Mexico, with a total extent of occurrence in this range of approximately $1,815 \mathrm{~km}^{2}$ and with an estimated area of occupancy of $730 \mathrm{~km}^{2}$, commonly 
over 1,800 m (Ruedas 1998). For a long time it was considered as a subspecies of Sylvilagus floridanus. It occurs in small population densities, which increases its sensitivity to threats. It is likely sensitive to drought since it occurs less frequently in dry years. The destruction of its habitat due to urbanization, development, grazing cattle, and cutting of shrubs is reducing the available habitat for the species (Ruedas 1998).

Conservation proposals. Detailed studies are required to determine the best actions for its conservation, including population genetics, life history, population status, and the effects of its threats, followed by the establishment of protected areas and appropriate management plans. Monitoring of this species is necessary because it also experiences extreme fluctuations in number of mature individuals because of drought and other threats (Ruedas 1998).

\section{Discussion}

State of knowledge. Less than $55 \%$ (7/13 species) of the total number of endangered and critically endangered lagomorph species has been subject of specific study in recent works (2011 to date), and in some cases only one publication was found. The lack of recent knowledge for many of the species of lagomorphs worldwide may be due to several factors that have limited their study. For example, lack of institutional support or funding sources; reduced academic staff to perform studies (only 66 members in the Lagomorph Specialist Group of the IUCN); lack of security conditions in the areas where these species are distributed; and/or difficulty involved in capture and taxonomic identification of some taxa. For species with restricted distribution, endemic, and in the categories of critically endangered and endangered, these factors are compounded even more; they are potentially vulnerable to the effects of the changes associated with the destruction of their habitats induced by humans and climate change, hindering their observation and thus their study.

The current trends in the state of knowledge of endangered and critically endangered lagomorphs worldwide indicate that the research areas of phylogeny, systematics, taxonomy and evolution are the most represented, followed by conservation and ecology. For P. furnessi and all the species of Sylvilagus more studies are necessary in all research areas in biology to know the current conservation status and propose specific conservation actions. The species with the largest number of studies is $O$. iliensis with 11 studies on ecology, conservation, phylogeny, systematics, taxonomy and evolution, followed by 0 . koslowi with 10 studies in the same areas. The species that have very few studies are S. graysoni and S. insonus.

The regions where endangered and critically endangered lagomorph species are most numerous (Central America and East Central Asia) are generally recognized as biodiversity hotspots, places with their own biogeographic history, and with ecosystems (such as cloud and temperate forest) which support biological diversity, have high numbers of endemic species, and are often severely threatened (Myers et al. 2000). Thus they must be priority sites for conservation. Moreover, it is very important to generate proposals for conservation for the species of lagomorphs in critical risk categories, from a biogeographical perspective. Prioritizing areas for conservation and reincorporating these relevant and under-represented species in the system of natural protected areas should play a very important role in the decision-making process.

Conservation. Human activities in the world have directly and indirectly affected the survival of lagomorph species, especially those with restricted distributions. Changes in agricultural practices, including the use of fertilizers and pesticides, as well as increase of monocultivation and the burning of pastures for livestock, have an impact on the declining populations of lagomorphs. Decisions regarding land use should consider the impact of other factors, such as conservation, hunting, fur industry, and the increase in human settlements. 
Similarly, it is of great importance to propose management alternatives and urgent actions of protection, conservation, and recovery of subspecies considered historically widely distributed, for example, S. bachmani peninsularis and S. b. exiguus in the Baja California Peninsula, whose populations are considered threatened and require immediate conservation actions, including their habitats. Sylvilagus b. peninsularis could be considered as extinct by anthropogenic activities (Lorenzo et al. 2013). Sylvilagus b. riparius is a candidate to be recorded as critically endangered on the red list of the IUCN; it is found along streams of the lower reaches of the San Joaquin River in California, U.S.A. It occupies approximately 225 hectares in two separate areas, one of which is highly fragmented. One population has been reduced to about $25 \%$ of its size based on population censuses in the past 11 years. Part of its habitat is intended for urban development in the coming decade. A third population has recently been established in a historic habitat, but it is too early to determine if the restored population will be viable (Kelly et al. 2004; Williams et al. 2008). Field studies are necessary to determine the current status of S. floridanus yucatanicus in the Yucatan Peninsula (Escobedo-Cabrera and Lorenzo 2011), S. brasiliensis truei in southeastern Mexico, and S. cunicularius cunicularius in central and western Mexico, which share the threat of habitat fragmentation.

Populations of $L$. callotis callotis and L. callotis gaillardi in northwestern, central, and southern Mexico have shown a drastic decline mainly due to the loss and degradation of their habitat (NMDGF 1988) by sport hunting, habitat disturbance and fragmentation, provoked fires (MartínezVilleda 2006), and tending to be displaced by more generalist species such as $L$. californicus or Sylvilagus spp. (Bednarz and Cook 1984; Desmond 2004; Brown et al. in press). Although recent efforts have generated knowledge about the state of conservation and threat factors of some species of endemic lagomorphs, it is still necessary to carry out more detailed and long-term studies to propose management plans and conservation of their habitats in collaboration with society and academic and institutional sectors.

To protect population s of lagomorphs from disappearing, it is necessary to perform simultaneous actions of conservation and controlled use, as well as to increase life quality for local residents to reduce pressure on the species and their habitats through improving production activities (fishing and livestock). For some of the species of insular rabbits and hares their future seems uncertain; although there are conservation schemes in operation, and some are in protected areas, some threats to their populations still remain. Local protected natural areas may represent a viable alternative for the conservation of lagomorphs and improvement in life quality of residents in other areas. Unfortunately, in many countries, efforts on research and protection on rabbits and wild hares are scarce. It is very important to increase studies of poorly known lagomorphs for their proper utilization and conservation.

In addition, there are substantial gaps in information regarding biology of several species (eight species have deficient data in the IUCN), which becomes relevant considering that without this information, it would not be possible to make an adequate assessment of the conservation status and threats they face, and any species management plan and their habitats would likely be unsuccessful. More than $40 \%$ (6 species) of endangered and critically endangered species have no recent studies. It is necessary to know the current state of the populations of the lagomorphs in depth, carry out long-term studies on population dynamics including their relationship with other species of native fauna and flora as well as the effects of exotic species present.

Control of exotic species is a conservation priority for insular lagomorphs, including control and management of feral animals (dogs and cats) that directly attack their young. Surveillance carried out by elements of the local authorities is recommended to prevent poaching.

For some species, breeding programs are recommended in certified semi-captivity units, for 
management and use of wildlife to ensure sustainable consumption by generating extra income to its inhabitants. In addition, environmental education campaigns that promote the conservation and controlled use of plants and animals should be established permanently at different levels. These programs must have the objective of disseminating the results of investigations and the role played by the lagomorphs in their ecosystems, as well as the impacts that affect them with human activities. It is essential to include local authorities and population in the strategies developed, because any conservation program would be a failure without their support.

\section{Resumen}

Introducción: Los lagomorfos (conejos, liebres y pikas) están ampliamente distribuidos en todos los continentes, excepto Antártica. Comprenden 91 especies: 31 conejos de los géneros Brachylagus, Bunolagus, Caprolagus, Nesolagus, Pentalagus, Poelagus, Prolagus, Pronolagus, Romerolagus y Sylvilagus; 32 liebres del género Lepus y 28 pikas del género Ochotona. De acuerdo a la lista de especies amenazadas de la IUCN (2014), una está extinta, tres están críticamente en peligro, 10 en peligro, cinco cercanas a la amenaza, cinco vulnerables, 61 en preocupación menor y seis con datos deficientes. Algunas de sus poblaciones están declinando a ritmo acelerado por actividades humanas y el cambio climático. Con el fin de determinar acciones específicas de conservación para las especies en riesgo en un futuro cercano, el objetivo de este estudio es presentar el estado de conocimiento para las especies en peligro y críticamente en peligro y ofrecer propuestas de conservación basadas en estudios recientes. Este estudio puede servir como un punto de partida para proponer planes de manejo y conservación del hábitat para estas especies y conocer los huecos de información para atenderlos lo más pronto posible.

Metodología: Presentamos un análisis de las recientes tendencias del estado del conocimiento de las especies de lagomorfos en peligro y críticamente en peligro a nivel mundial, con base en la recopilación de citas bibliográficas recientes, obtenidas de la lista roja de la IUCN (2014), la página de la red mundial del Grupo Especialista de los Lagomorfos de la IUCN y de estudios focales de sus especies. Cada estudio fue separado por varios temas para conocer cuáles necesitan atención. Presentamos información detallada para las especies en riesgo de extinción en un futuro cercano (en peligro y críticamente en peligro), describiendo las amenazas a sus poblaciones y propuestas de conservación existentes.

Resultados: Un total de 13 especies de lagomorfos en peligro y críticamente en peligro han sido sujetos de estudio, con un total de 78 artículos; los más representados (25) se refieren al tema de filogenia, sistemática, taxonomía y evolución, seguidos por el tema de conservación (18) y ecología (14); y los menos representados son los estudios de reproducción y morfología con un estudio cada uno. Las especies críticamente en peligro y en peligro tienen distribuciones restringidas y en general, sus factores de amenaza son: la introducción de especies exóticas; la pérdida de su hábitat por el desarrollo de asentamientos humanos y actividades productivas; los incendios inducidos para el crecimiento de nuevo pasto para el ganado; la cacería furtiva; la presencia de perros ferales y depredadores silvestres.

Discusión y conclusiones: Las actividades humanas en el mundo han afectado la supervivencia de las especies de lagomorfos, especialmente aquellas con distribuciones restringidas. Menos del $55 \%$ (7 especies) del total de las especies de lagomorfos en peligro y críticamente en peligro han sido sujeto de estudio en trabajos recientes (2011 a la fecha); además, en algunos casos se encontró solo una publicación. Aunque los esfuerzos recientes han generado conocimiento sobre el estado de conservación y factores de amenaza de algunas especies de lagomorfos endémicos, es necesario llevar a cabo estudios más detallados y a largo plazo y para proponer planes de manejo y conservación de su hábitat en colaboración con la sociedad y los diferentes sectores académicos e institucionales.

Palabras clave: categoría de riesgo, conejos, conservación, endemismo, lagomorfos, liebres, pikas.

\section{Acknowledgments}

We thank D. Dorantes for editorial services in English; R. Owen and two anonymous reviewers for their very useful comments for improving the manuscript.

\section{References}

[1] Abrantes, J., C. R. Carmo, C. A. Matthee, F. Yamada, W. van der Loo, and P. J. Esteves. 2011. A shared unusual genetic change at the chemokine receptor type 5 between Oryctolagus, Bunolagus and Pentalagus. Conservation Genetics 12:325-330. 
[2] Acosta-MontesdeOca, A., T. Zariñán, H. Macías, M. A. Pérez-Solís, A. Ulloa-Aguirre, and R. GutiérrezSAGAL. 2012. Cloning the uteroglobin gene promoter from the relic volcano rabbit (Romerolagus diazi) reveals an ancient estrogen-response element. Molecular Reproduction and Development 79:337-345.

[3] Álvarez-Castañeda, S. T., and A. Ortega-Rubio. 2003. Current status of rodents on islands in the Gulf of California. Biological Conservation 109:157-163.

[4] Aryal, A., and H. Kumar. 2010. First cameras trap sighting of critically endangered Hispid hare (Caprolagus hispidus) in Shuklaphanta Wildlife Reserve-Nepal. World Applied Sciences Journal 9:367-371.

[5] Aryal A., D. Brunton, W. JI, H. K. Yadav, B. Adhikari, and D. Raubenheimer. 2012. Diet and habitat use of Hispid hare Caprolagus hispidus in Shuklaphanta Wildlife Reserve, Nepal. Mammal Study 37:147154.

[6] Bednarz, J. C., AND J. A. Cook. 1984. Distribution and numbers of the white-sided jackrabbit (Lepus callotis gaillardi) in New Mexico. Southwestern Association of Naturalists 29:358-360.

[7] Bonnaud, E., F. M. Medina, E. Vidal, M. Nogales, B. Tershy, E. Zavaleta, C. J. Donlan, B. Keitt, M. L. Corre, and S. V. Horwath. 2011. The diet of feral cats on islands: a review and a call for more studies. Biological Invasions 13:581-603.

[8] Brown, D. E., R. D. Babb, C. Lorenzo, and M. M. Altemus. In press. Ecology of the antelope jackrabbit (Lepus alleni). The Southwestern Naturalist.

[9] Carrillo-Reyes, A., C. Lorenzo, T., E. J. Naranjo, and M. Pando-Moreno. 2012. Habitat use of the endangered hare, Lepus flavigularis: conservation implications. Therya 3:113-125.

[10] Caughley, G., And A. Gunn. 1996. Conservation Biology in Theory and Practice. Blackwell Science: Cambridge.

[11] Cervantes, F. A., And C. Lorenzo. 1997. Sylvilagus insonus. Mammalian Species 568:1-4.

[12] Cervantes, F. A., C. Lorenzo, and F. X. González-Cózatl. 2004. The Omiltemi rabbit (Sylvilagus insonus) is not extinct. Mammalian Biology 69:61-64.

[13] Cervantes, F. A., Lorenzo, C., Farías, and J. Vargas. 2008. Lepus flavigularis. The IUCN Red List of Threatened Species. Version 2014.3. <www.iucnredlist.org>. Downloaded on 20 December 2014.

[14] Chapman, J. A., and G. Ceballos. 1990. Chapter 5: The Cottontails. Pp. 95-110 in Rabbits, hares and pikas, Status Survey and Conservation Action Plan (Chapman, J. A., and J. E. C. Flux, eds.). International Union for the Conservation of Nature and Natural Resources. Gland, Switzerland.

[15] Chapman, J. A., AND J. E. C. Flux. 1990. Chapter 1: Introduction and Overview of the Lagomorphs. Pp. 1-13 in Rabbits, hares and pikas. Status Survey and Conservation Action Plan (Chapman, J. A., and J. E. C. Flux, eds.). International Union for the Conservation of Nature and Natural Resources. Gland, Switzerland.

[16] Chapman, J. A., J. E. C. Flux, A. T. Smith, D. J. Bell, G. G. Ceballos, K. R. Dixon, F. C. Dobler, N. A. Formozov, R. K. Ghose, W. L. R. Oliver, T. Robinson, E. Schneider, S. N. Stuart, K. Sugimurua, and Z. Changlin. 1990. Chapter 14: Conservation action needed for rabbits, hares and pikas. Pp.154-168 in Rabbits, hares and pikas, Status Survey and Conservation Action Plan (Chapman, J. A., and J. E. C. Flux, eds.). International Union for the Conservation of Nature and Natural Resources. Gland, Switzerland.

[17] Chapman, J. A., And J. E. C. Flux. 2008. Introduction to the Lagomorpha. Pp. 1-9 in Lagomorph Biology: Evolution, Ecology and Conservation (Alves, P. C., N. Ferrand, and K. Hackländer, eds.). Springer-Verlag, Berlin Heidelberg. New York, EE.UU.

[18] Chung, T. R. K. 2008. The current status of Lagomorphs in Asia. Thesis of Master of Science in European Forestry, Institute of Wildlife Biology and Game Management, University of Natural Resources and Applied Life Sciences. Vienna, Austria. 
[19] Cody, M. L., and E. Velarde. 2002. Appendix 10.7. Raptors, owls and goatsuckers. Pp. 615-619 in A New Island Biogeography of the Sea of Cortés (Case, T. J., M. L. Cody, and E. Ezcurra, eds.). 2 d. edition. Oxford University Press. New York, EE.UU.

[20] Collins, K., V. Ahlman, C. Matthee C., P. Taylor, M. Keith, G. Palmer, and A. Van Jaarsveld. 2004. Bunolagus monticularis. Pp. 412-413 in Red Data Book of the Mammals of South Africa: A Conservation Assessment (Friedman, Y., and B. Daly, eds.). CBSG Southern Africa, Conservation Breeding Specialist Group (SSC/IUCN), Endangered Wildlife Trust. Parkview, South Africa.

[21] Desmond, M. J. 2004. Habitat associations and co-occurrence of Chihuahuan Desert Hares (Lepus californicus and L. callotis). The American Midland Naturalist 151:414-419.

[22] Dobler, F. C., AND K. R. Dixon. 1990. Chapter 6: The pygmy rabbit Brachylagus idahoensis. Pp.111-115 in Rabbits, hares and pikas: Status survey and Conservation Action Plan (Chapman, J. A., and J. E. C. Flux, eds.). International Union for the Conservation of Nature and Natural Resources. Gland, Switzerland.

[23] Duthie, A. G., And T. J. Robinson. 1990. Chapter 8: The African Rabbits. Pp. 121-127 in Rabbits, hares and pikas: Status Survey and Conservation Action Plan (Chapman, J. A., and J. E. C. Flux, eds.). International Union for the Conservation of Nature and Natural Resources. Gland, Switzerland.

[24] Erbajeva, M. A., AND Ma, Y. 2006. A new look at the taxonomic status of Ochotona argentata Howell, 1928. Acta Zoologica Cracoviensia 49A:135-149.

[25] Escobedo-Cabrera, E., and C. Lorenzo. 2011. Nuevos registros de Sylvilagus floridanus en la Península de Yucatán, México. Therya 2:279-283.

[26] Espinosa-Gayosso, C. V., and S. T. Álvarez-Castañeda. 2006. Status of Dipodomys insularis, an endemic species of San José Island, Gulf of California, Mexico. Journal of Mammalogy 87:677-682.

[27] FA, J. E., AND D. J. Bell. 1990. Chapter 12:The volcano rabbit Romerolagus diazi. Pp.143-146 in Rabbits, hares and pikas, Status Survey and Conservation Action Plan (Chapman, J. A., and J. E.C. Flux, eds.). International Union for the Conservation of Nature and Natural Resources. Gland, Switzerland.

[28] Flux, J. E. C., and R. Angermann. 1990. Chapter 4: The hares and jackrabbits. Pp. 61-94 in Rabbits, hares and pikas, Status Survey and Conservation Action Plan (Chapman, J. A., and J. E. C. Flux, eds.). International Union for the Conservation of Nature and Natural Resources. Gland, Switzerland.

[29] Flux, J. E. C., A. G. Duthie, T. J. Robinson, And J. A. Chapman. 1990. Chapter 13: Exotic populations. Pp. 147-153 in Rabbits, hares and pikas, Status Survey and Conservation Action Plan (Chapman, J. A., and J. E. C. Flux, eds.). International Union for the Conservation of Nature and Natural Resources. Gland, Switzerland.

[30] Formozov, N. A., E. L. Yakhontov, and P. P. Dmitriyev. 1996. New form of Alpine pika Ochotona alpina hoffmanni ssp. n. from Hentiyn Nuruu Ridge Mongolia and probable natural history of this species. Byulleten' Moskovskogo Obshchestva Ispytateley Prirody, Otdel Biologicheskii 101:28-36.

[31] Formozov, N. A. 1997. Pikas (Ochotona) of the world: systematics and conservation. Game Wildlife 14:506-507.

[32] Formozov, N. A., and I. Yu. Baklushinskaya. 1999. The species status of a new pika (Ochotona hoffmanni) and its inclusion in the list of Russian fauna. Byulleten' Moskovskogo Obshchestva Ispytateley Prirody, Otdel Biologiche- skii 104:68-72.

[33] Formozov, N. A., I. Yu. Baklushinskaya, and Y. MA. 2004. Taxonomic status of the Helan-Shan pika, Ochotona argentata, from the Helan-Shan Ridge (Ningxia, China). Zoologicheskii Zhumal 83:9951007.

[34] Ge, D., Z. Zhang, L. XIA, Q. Zhang, Y. MA, and Q. Yang. 2012. Did the expansion of $C_{4}$ plants drive extinction and massive range contraction of micromammals? Inferences from food preference and historical biogeography of pikas. Palaeogeography, Palaeoclimatology, Palaeoecology 326328:160-171. 
[35] Gómez-Nísıno, A. 2006. Ficha técnica de Sylvilagus mansuetus. Pp. 1-5 in Los mamíferos mexicanos en riesgo de extinción según el PROY-NOM-059-ECOL-2000 (Medellín, R., comp.). Instituto de Ecología, Universidad Nacional Autónoma de México. Bases de datos SNIB-CONABIO. Proyecto No. W005. Mexico City, Mexico.

[36] Hoffmann, R. S., And A. T. Smith. 2005. Order Lagomorpha. Pp. 185-211 in Mammal species of the world: a taxonomic and geographic reference (Wilson, D. E., and D. M. Reeder, eds.). 3rd ed. Johns Hopkins University Press. Baltimore, EE.UU.

[37] Hughes, G. O., W. Thuiller, G. F. Midgley, And K. Collins. 2008. Environmental change hastens the demise of the critically endangered riverine rabbit (Bunolagus monticularis). Biological Conservation 141:23-34.

[38] IUCN (International Union for Conservation of Nature). 2014. IUCN Red List of Threatened Species. Version 2014.2. <www.iucnredlist.org >. Downloaded on 28 June 2014.

[39] Jiménez-Almaráz, T., J. Juárez, and L. León. 1993. Mamíferos. Pp. 503-549 in Historia Natural del Parque Ecológico Estatal Omiltemi, Chilpancingo, Guerrero, México (Luna, I. V., and J. Llorente, eds.). Comisión Nacional para el Conocimiento y Uso de la Biodiversidad and Universidad Nacional Autónoma de México. Mexico City, Mexico.

[40] Kelly, P., D. Williams, L. Hamilton, M. Lloyd, and E. Williams. 2004. The riparian brush rabbit (Sy/vilagus bachmani riparius): an overview of its status and recovery. Pp. 62 in 2nd World Lagomorph Conference (Alves, P. C., and N. Ferrand, eds). CIBIO. Vairao, Portugal.

[41] Kubo, M., H. Sato, S. Hattori, and T. Kuraishi. 2014. Dermatitis associated with infestation of a trombiculid mite, Leptotrombidium miyajimai, in an Amami Rabbit (Pentalagus furnessi). Journal of Wildlife Diseases 50:416-418.

[42] KumaR, U. M., AND S. N. Bahuguna. 2014. Molecular phylogeny of mouse hare (Ochotona: Lagomorpha) using cytochrome b gene as a phylogenetic marker. International Journal of Science and Research 3:220-226.

[43] Lanier, H. C., and O. Link E. 2009. Inferring divergence times within pikas Ochotona spp. using mtDNA and relaxed molecular dating techniques. Molecular Phylogenetics and Evolution 53:1-12.

[44] Leach, K., R. Kelly, A. Cameron, W. I. Montgomery, and N. Reid. 2014. Expertly validated models suggest responses to climate change are related to species traits: a phylogenetically-controlled analysis of the Order Lagomorpha. bioRxiv BETA. http://biorxiv.org/ Downloaded on 08 December 2014.

[45] Lı, W., J. MA, AND M. HA. 1994. A preliminary research on the artificial feeding of lli pika. Chinese Journal of Vector Biology and Control 5:130-133.

[46] Lı, W., H. Chang, AND Z. Liu. 2000. On the status of Ochotona koslowi in the East Kunlun Mountains of China. Chinese Journal of Zoology 35:28-31.

[47] Lו, W. D. 2004. The discovery and research on Ili Pika (Ochotona iliensis). Chinese Journal of Zoology 39:106-111.

[48] LI, W., AND A. T. Smıth. 2005. Dramatic decline of the threatened Ili pika Ochotona iliensis (Lagomorpha: Ochotonidae) in Xinjiang, China. Oryx 39:30-34.

[49] Lı, W., H. Zhang, AND Z. Lıu. 2006. Brief report on the status of Kozlov's pika, Ochotona koslowi (Büchner), in the east Kunlun mountains of China. Integrative Zoology 1:22-24.

[50] Lin, G., H. Ci, S. J. Thirgood, T. Zhang, and J. Su. 2010. Genetic variation and molecular evolution of endangered Kozlov's pika (Ochotona koslowi Büchner) based on mitochondrial cytochrome b gene. Polish Journal of Ecology 58:563-568.

[51 Lissovsky, A. A., N. V. Ivanova, And A. V. Borisenko. 2007. Molecular phylogenetics and taxonomy of the subgenus Pika (Ochotona, Lagomorpha). Journal of Mammalogy 88:1195-1204.

[52] Lorenzo, C., S. T. Álvarez-Castañeda, and J. Vázquez. 2011. Conservation status of the threatened, insular San Jose brush rabbit (Sylvilagus mansuetus). Western North American Naturalist 71:10-16. 
[53] Lorenzo, C., P. Cortés-Calva, G. Ruiz-Campos, and S. T. Álvarez-Castañeda. 2013. Current distributional status of two subspecies of Sylvilagus bachmani on the Baja California Peninsula, Mexico. Western North American Naturalist 73:219-223.

[54] Lorenzo, C., A. Carrillo-Reyes, T. M. Rioja-Paradela, M. De La Paz C., J. Bolaños-Citalán, and S. T. Álvarez-Castañeda. 2014. Estado actual de conservación de liebres y conejos en categoría de riesgo en México. Informe final. Proyecto HK052. CONABIO. Mexico City, Mexico.

[55] MacPhee, R., and C. Fleming. 1997. Brown-eyed, milk-giving... losing mammals since A.D. 1500. Natural History 106:84-85.

[56] MacPhee, R., and C. Fleming. 1999. Requiem Aeternam. The last five hundred years of mammalian species extinctions. Pp. 333-371 in Extinctions in Near Time (MacPhee, R. D. E., ed.). Kluwer Academic/Plenum Publishers. New York, EE.UU.

[57] Maheswaran, G., AND A. T. Smith. 2008. Caprolagus hispidus. The IUCN Red List of Threatened Species. Version 2014.3. <www.iucnredlist.org >. Downloaded on 08 December 2014.

[58] Martínez-García, J. A. 2011. Densidad, uso y evaluación del hábitat y de la dieta de Romerolagus diazi en el Parque Nacional Izta-Popo, Zoqiapan y Anexas. Tesis de Doctorado. Colegio de Posgraduados. Montecillo, México.

[59] Martínez-García, J. A., G. D. Mendoza, M. Sánchez-Trocino, P. A. Hernández, F. X. Plata, and M. M. CRosby. 2011. Defecation rate in Romerolagus diazi fed with different levels of Muhlenbergia macroura. Journal of Applied Animal Research 39:317-319.

[60] Martínez-García, J. A., G. D. Mendoza-Martínez, J. L. Alcantara-Carbajal, L. A. Tarango-Arámbula, T. Sánchez-Torres-Esqueda, R. R. Lara, and P. A. Hernández-García. 2012. Composición de la dieta y capacidad de carga del hábitat del conejo de los volcanes (Romerolagus diazi) en México. Revista Chapingo. Serie Ciencias Forestales y del Ambiente 18:423-434.

[61] Martínez-Villeda, E. 2006. Efecto del cambio climático en la distribución espacio-temporal de dos lagomorfos en México. Tesis de Maestría. Instituto de Biología, Univeridad Nacional Autónoma de México.

[62] Myers, N., R. A. Mittermeier, C. G. Mittermeier, G. A. B. da FonsecA, And J. Kent. 2000. Biodiversity hotspots for conservation priorities. Nature 403:853-858.

[63] Nalls, A. V., L. K. Ammerman, And R. C. Dowler. 2012. Genetic and morphologic variation in the Davis Mountains Cottontail (Sy/vilagus robustus). The Southwestern Naturalist 57:1-7.

[64] Nalls, A. V., L. K. Ammerman, And R. C. Dowler. 2014. Genetic variation in the Davis Mountains cottontail (Sylvilagus robustus) from the Chisos Mountains based on mitochondrial DNA sequence. Pp. 205-210 in Proceedings of the Sixth Symposium on the Natural Resources of the Chihuahuan Desert Region (Hoyt, C. A., and J. Karges, eds.). Chihuahuan Desert Research Institute. Fort Davis, EE.UU.

[65] Nelson, E. W. 1904. Description of seven new rabbits from Mexico. Proceedings of the Biological Society of Washington 7:103-110.

[66] Neves, F., J. Abrantes, A. Pinheiro, T. Almeida, P. P. Costa, and P. J. Esteves. 2014. Convergent evolution of IL- 6 in two leporids (Oryctolagus and Pentalagus) originated an extended protein. Immunogenetics 66:589-595.

[67] Ning, Y., AND Z. Changlin. 1992. The phylogenetic analysis of subgenus Ochotona of China. Northwest Plateau Institute of Biology, Academia Sinica, Xining, Beijing.

[68] NiU, Y., F. Wel, M. Lı, X. Liu, And Z. Feng. 2004. Phylogeny of pikas (Lagomorpha, Ochotona) inferred from mitochondrial cytochrome b sequences. Folia Zoologica 53:141-155.

[69] NMDGF (New Mexico Department of Game And Fish). 1988. Handbook of Species Endangered in New Mexico. Endangered Species Act in the Office of Endangered Species U.S. Fish and Wildlife Service. United States Department of Interior. G-146:1-2. 
[70] Portales, G. B., P. Romero, Z. Rangel, P. Domínguez, C. Velázquez, A. Cruz, R. Sierra, Ch. Campos, C. López, C. Rangel, and J. Ramírez-Silva. 2004. Actions for the conservation of Mexican Lagomorphs. Pp. 190 in 2nd World Lagomorph Conference (Alves, P. C., and N. Ferrand, eds.). CIBIO. Vairao, Portugal.

[71] Rioja T., C. Lorenzo, E. Naranjo, L. Scott, and A. Carrillo-Reyes. 2011. Breeding and parental care in the endangered Tehuantepec jackrabbit (Lepus flavigularis). Western North American Naturalist 71:56-66.

[72] Rioja-Paradela, T., A. Carrillo-Reyes, and C. Lorenzo. 2012. Análisis de población viable para determinar el riesgo de extinción de la liebre de Tehuantepec (Lepus flavigularis) en Santa María del Mar, Oaxaca. Therya 3:137-150.

[73] Rioja, T., And A. Carrillo-Reyes. 2014. Desarticulación entre políticas públicas para la conservación de la vida silvestre y la mitigación de la pobreza: el caso de la liebre de Tehuantepec (Lepus flavigularis) y pueblos indígenas del sureste de Oaxaca, México. Pp.175-204 in Gestión territorial y manejo de recursos naturales: fauna silvestre y sistemas agropecuarios (Medina-Sanson, L., C. Tejeda-Cruz, A. Carrillo-Reyes, T. M. Rioja-Paradela, eds.). Universidad Autónoma de Chiapas. Tuxtla Gutierrez, México.

[74] Rizo-Aguilar, A., J. A. Guerrero, M. G. Hidalgo-Mihart, and A. González-Romero. 2014. Relationship between the abundance of the Endangered volcano rabbit Romerolagus diazi and vegetation structure in the Sierra Chichinautzin mountain range, Mexico. Oryx FirstView 1-6.

[75] Rizo-Aguilar, A., J. A. Guerrero, A. M. P. Montoya-Lara, and C. Valdespino. 2014. Physiological stress in volcano rabbit Romerolagus diazi populations inhabiting contrasting zones at the Corredor Biologico Chichinautzin, Mexico. Mammalian Biology - Zeitschrift für Säugetierkunde 79:357-361.

[76] Romero, F. J., and A. Velazquez. 1994. El conejo Zacatuche: tan lejos de Dios y tan cerca de la Ciudad de México. Instituto Nacional de Ecología, Consejo Nacional de la Fauna. Mexico City, Mexico.

[77] Romero-Palacios, A., And F. A. Cervantes. 2012. Comparación del esmalte dental de los molariformes en las liebres mexicanas. Therya 3:207-222.

[78] RuedAs, L. A. 1998. Systematics of Sy/vilagus Gray, 1867 (Lagomorpha: Leporidae) from southwestern North America. Journal of Mammalogy 79:1355-1378.

[79] Ruf, I. 2014. Comparative Anatomy and Systematic Implications of the Turbinal Skeleton in Lagomorpha (Mammalia). The Anatomical Record 297:2031-2046.

[80] Sánchez-Trocino, M., G. D. Mendoza, F. Gual-Sill, F. X. Plata, J. A. Martínez, H. Lee, and M. M. Crosby. 2013. The effect of Muhlenbergia macroura dietary level on intake, digestibility and weight changes in volcano rabbit (Romerolagus diazi). Journal of Applied Animal Research 41:234-239.

[81] Sántiz, E. C., A. González-Romero, C. Lorenzo, S. Gallina-Tessaro, and F. C. Cervantes. 2012. Uso y selección de asociaciones vegetales por la liebre de Tehuantepec (Lepus flavigularis) en Oaxaca, México. Therya 3:127-136.

[82] Semarnat (Secretaría De Medio Ambiente Y Recursos Naturales). 2010. Norma Oficial Mexicana NOM059-SEMARNAT-2010, Protección ambiental-Especies nativas de México de flora y fauna silvestresCategorías de riesgo y especificaciones para su inclusión, exclusión o cambio- Lista de especies en riesgo. Diario Oficial de la Federación, Segunda Sección, págs. 1-78, Jueves 30 de Diciembre. Mexico City, Mexico.

[83] Smith, A. T., N. A. Formozov, R. S. Hoffmann, Z. Changlin, and M. A. Erbajeva. 1990. Chapter 3:The Pikas. Pp. 14-60 in Rabbits, hares and pikas, Status Survey and Conservation Action Plan (Chapman, J. A., and J. E.C. Flux, eds.). International Union for the Conservation of Nature and Natural Resources. Gland, Switzerland.

[84] Sмітн, A. T. 2008. Conservation of endangered lagomorphs. Pp. 297-315 in Lagomorph Biology: Evolution, Ecology and Conservation (Alves, P. C., and K. Hackländer, eds.). Springer-Verlag, Berlin Heidelberg. New York, EE.UU. 
[85] Sмith, A. T., AND C. H. Johnston. 2008. Ochotona argentata. IUCN 2011. IUCN Red List of Threatened Species. Version 2011.2. bwww.iucnredlist.org>. Downloaded on 07 February 2012.

[86] Smith A. T., ANd Y. XIE. 2008. A guide to the mammals of China. Princeton University Press. New Jersey, EE.UU.

[87] South African Mammal Camp Workshop. 2013. Bunolagus monticularis. The IUCN Red List of Threatened Species. Version 2014.3. <www.iucnredlist.org>. Downloaded on 08 December 2014.

[88] Stoner, Ch. J., O. R. P. Bininda-Emonds, And T. Caro. 2003. The adaptive significance of coloration in lagomorphs. Biological Journal of the Linnean Society 79:309-328.

[89] Sugimura, K., S. Sato, F. Yamada, S. Abe, H. Hirakawa, and Y. Handa. 2000. Distribution and abundance of the Amami rabbit Pentalagus furnessi in the Amami and Tokuno Islands, Japan. Oryx 34:198-206.

[90] Sugimura, K., F. Yamada, And A. Miyamoto. 2003. Population trend, habitat change and conservation of the unique wildlife species on Amami Island, Japan. Global Environmental Research 7:79-89.

[91] Sugimura, K., And F. Yamada. 2004. Estimating population size of the Amami rabbit Pentalagus furnessi based on fecal pellet counts on Amami Island, Japan. Acta Zoologica Sinica 50:519-526.

[92] Sugimura, K., K. Ishida, S. Abe, Y. Nagal, Y. Watari, M. Tatara, M. Takashi, T. Hashimoto, and F. Yamada. 2014. Monitoring the effects of forest clear-cutting and mongoose Herpestes auropunctatus invasion on wildlife diversity on Amami Island, Japan. Oryx 48:241-249.

[93] Tandan P., B. Dhakal, K. Karki, and A. Aryal. 2013. Tropical grasslands supporting the endangered hispid hare (Caprolagus hispidus) population in the Bardia National Park, Nepal. Current Science 105:691-694.

[94] [Velázquez, A., F. J. Romero, and J. López-Paniagua. 1996. Ecología y conservación del conejo zacatuche y su hábitat. Ediciones Científicas Universitarias Serie Texto Científico Universitario. Universidad Nacional Autónoma de México, Fondo de Cultura Económica. Mexico City, Mexico.

[95] Watari, Y., S. NishiJima, M. Fukasawa, F. Yamada, S. Abe, and T. Miyashita. 2013. Evaluating the "recovery level" of endangered species without prior information before alien invasion. Ecology and Evolution 3:4711-4721.

[96] Watari, Y., S. Nishijima, M. Fukasawa, F. Yamada, S. Abe, and T. Miyashita. 2013. The effect of Muhlenbergia macroura dietary level on intake, digestibility and weight changes in volcano rabbit (Romerolagus diazi). Journal of Applied Animal Research 41:234-239.

[97] Williams, D. F., P. A. Kelly, L. P. Hamilton, M. R. Lloyd, E. A. Williams, and J. J. Youngblom. 2008. Recovering the endangered Riparian Brush rabbit (Sylvilagus bachmani riparius): reproduction and growth in confinement and survival after translocation. Pp 349-363 in Lagomorph Biology: Evolution, Ecology and Conservation (Alves, P. C., N. Ferrand, and K. Hackländer, eds). SpringerVerlag, Berlin Heidelberg. New York, EE.UU.

[98] WiLson, D. E. 1991. Especímenes tipo de mamíferos mexicanos en el National Museum of Natural History, Washington, D. C., EUA. Anales del Instituto de Biología. Serie Zoología 62:287-318.

[99] Wood, B., B. R. Tershy, M. A. Hermosillo, C. J. Donlan, J. A. Sánchez, B. S. Keitt, D. A. Croll, G. R. Howald, AND N. BiavasCHI. 2002. Removing cats from islands in north-west Mexico. Pp. 374-380 in Turning the Tide: the Eradication of Invasive Species (Veitch, C. R., and M. N. Clout, eds.). World Conservation Union Species Survival Committee, Invasive Species Specialist Group. Gland, Switzerland, Cambridge, United Kingdom.

[100] Yamada, F. 2008. A review of the biology and conservation of the Amani rabbit (Pentalagus furnessi) (Stone 1900). Pp 363-368 in Lagomorph Biology: Evolution, Ecology and Conservation (Alves, P. C., N. Ferrand, and K. Hackländer, eds.). Springer-Verlag, Berlin Heidelberg. New York, EE.UU.

[101] YiFan, C., L. GongHua, L. XueFeng, and S. JianPing. 2009. Food habits of Ochotona koslowi. Chinese Journal of Zoology 44:58-62.

[102] Yu, N., Ch. Zheng, Y-P. Zhang, And W-H. LI. 2000. Molecular systematics of pikas (genus Ochotona) inferred from mitochondrial DNA sequences. Molecular Phylogenetics and Evolution 16:85-95. 
[103] ZhenG, C. L. 1986. Recovery of Kozlov's pika (Ochotona koslowi Büchner) in the Kunlun Mountains of Xinjiang Uygur Autonomous Region, China. Acta Theriologica Sinica 5:285.

Summited: September 8, 2014

Review: November 16, 2014

Accepted: January 28, 2015

Associated editor: Robert Owen 